\title{
Novel pathogenic VPS13A gene mutations in Japanese patients with chorea-acanthocytosis
}

Yoshiaki Nishida, MD, Masayuki Nakamura, MD, PhD, Yuka Urata, MD, Kei Kasamo, MD, Hanae Hiwatashi, MS, Izumi Yokoyama, BS, Masahiro Mizobuchi, MD, PhD, Kotaro Sakurai, MD, PhD, Yasushi Osaki, MD, Yukari Morita, MD, Masako Watanabe, MD, PhD, Kenji Yoshida, MD, Kiyomi Yamane, MD, PhD, Natsuki Miyakoshi, MD, Ryouichi Okiyama, MD, Takehiro Ueda, MD, PhD, Noritaka Wakasugi, MD, Yuji Saitoh, MD, PhD, Takashi Sakamoto, MD, PhD, Yuji Takahashi, MD, PhD, Ken Shibano, MD, PhD, Hideki Tokuoka, MD, Atsushi Hara, MD, Kazunari Monma, MD, PhD, Katsuhisa Ogata, MD, PhD, Keita Kakuda, MD, Hideki Mochizuki, MD, PhD, Takeo Arai, MD, PhD, Manabu Araki, MD, PhD, Takeshi Fujii, MD, PhD, Kazuto Tsukita, MD, Haruhi Sakamaki-Tsukita, MD, and Akira Sano, MD, PhD

Neurol Genet 2019;5:e332. doi:10.1212/NXG.0000000000000332

\section{Abstract \\ Objective}

To identify mutations in vacuolar protein sorting 13A (VPS13A) for Japanese patients with suspected chorea-acanthocytosis (ChAc).

\section{Methods}

We performed a comprehensive mutation screen, including sequencing and copy number variation $(\mathrm{CNV})$ analysis of the VPS13A gene, and chorein Western blotting of erythrocyte ghosts. As the results of the analysis, 17 patients were molecularly diagnosed with ChAc. In addition, we investigated the distribution of VPS13A gene mutations and clinical symptoms in a total of 39 molecularly diagnosed Japanese patients with ChAc, including 22 previously reported cases.

\section{Results}

We identified 11 novel pathogenic mutations, including 1 novel CNV. Excluding 5 patients with the unknown symptoms, $97.1 \%$ of patients displayed various neuropsychiatric symptoms or forms of cognitive dysfunction during the course of disease. The patients carrying the 2 major mutations representing over half of the mutations, exon 60-61 deletion and exon 37 c.4411C > T (R1471X), were localized in western Japan.

\section{Conclusions}

We identified 13 different mutations in VPS13A, including 11 novel mutations, and verified the clinical manifestations in 39 Japanese patients with ChAc.

\author{
Correspondence \\ Dr. Nakamura \\ nakamu36@ \\ m.kufm.kagoshima-u.ac.jp
}

\begin{abstract}
From the Kagoshima University Graduate School of Medical and Dental Sciences (Y.N., M.N., Y.U., K. Kasamo, H.H., I.Y., A.S.), Department of Psychiatry, Kagoshima, Japan; Epilepsy Center (M.M.), Department of Neurology, Nakamura Memorial Hospital, Hokkaido, Japan; Department of Psychiatry and Neurology (K. Sakurai.), Hokkaido University Graduate School of Medicine, Hokkaido, Japan; Department of Neurology (Y.O., Y.M.), Kochi Medical School, Kochi, Japan; Shinjyuku Neuro Clinic (M.W.), Tokyo, Japan; Department of Neurology (K. Yoshida and K. Yamane), Neurological Institute, Ohta-Atami Hospital, Fukushima, Japan; Department of Neurology (N.M., R.O.), Tokyo Metropolitan Neurological Hospital, Tokyo, Japan; Division of Neurology (T.U., H.T.), Kobe University Graduate School of Medicine, Hyogo, Japan; Department of Neurology (N.W., Y.S., T.S., Y.T., M.A.), National Center of Neurology and Psychiatry Hospital, Tokyo, Japan; Department of Neurology (K. Shibano), Akita Red Cross Hospital, Japan; Amagasaki General Medical Center (A.H.), Hyogo, Japan; Department of Neurology (K.M., K.O.), National Hospital Organization Higashisaitama National Hospital, Saitama, Japan; Department of Neurology (K. Kakuda, H.M.), Graduate School of Medicine, Osaka University, Japan; Ikebe Clinic (T.A.), Shizuoka, Japan; Department of Psychiatry (T.F.), National Center Hospital, National Center of Neurology and Psychiatry, Tokyo, Japan; Department of Neurology (K.T., H.S.-T.), Tenri Hospital, Nara, Japan; and Department of Neurology (K.T., H.S.-T.), Graduate School of Medicine, Kyoto University, Japan.
\end{abstract}




\section{Glossary}

cDNA = complementary DNA; ChAc = chorea-acanthocytosis; $\mathbf{C N V}=$ copy number variation; $\mathbf{g D N A}=$ genomic DNA; qPCR = quantitative PCR; VPS13A = vacuolar protein sorting $13 A$.

Chorea-acanthocytosis (ChAc) is a rare, autosomal recessive neurodegenerative disease characterized by adult-onset chorea, involuntary orofacial movement, peripheral acanthocytes, and various neuropsychiatric symptoms with loss-of-function mutations in vacuolar protein sorting $13 A$ (VPS13A), which consists of 73 exons spanning approximately $250 \mathrm{~kb}$ of chromosome $9 \mathrm{q} 21$. VPS13A encodes a protein with a molecular weight of approximately $360 \mathrm{kDa}$, named chorein. ${ }^{1,2}$ It is estimated that there are likely around $1000 \mathrm{ChAc}$ cases in the world. ${ }^{3}$ Although more than 100 patients with ChAc have so far been reported in Japan, the distribution of VPS13A mutations in Japan has not been conclusively determined. In this study, we report novel mutations in Japanese patients with ChAc. In addition, we investigate their clinical symptoms.

\section{Methods}

\section{Mutation analysis}

Coding and flanking regions of VPS13A (NC_000009.11) were analyzed by Sanger sequencing on an ABI PRISM 3130 Avant Genetic Analyzer (Thermo Fisher Scientific, Waltham, MA). ${ }^{4,5}$ For patients 16 and 17, we performed copy number variation $(\mathrm{CNV})$ analysis that has been previously described in detail. ${ }^{4,6}$

\section{Chorein analysis}

We performed chorein Western blotting analysis that has been previously described in detail ${ }^{4,7}$ with minor modifications. We used polyvinylidene difluoride membranes from GE Healthcare (Little Chalfont, United Kingdom) or Merck Millipore

Table 1 Profiles of the patients with ChAc in this study

\begin{tabular}{|c|c|c|c|c|c|c|c|c|c|c|c|c|}
\hline Pt no. & AO & $\mathbf{S}$ & C & Ac & Ch & $\mathbf{0}$ & Ep & NPS & FS & CK & AS & Res or Ori \\
\hline 1 & 35 & M & ND & $?$ & $?$ & + & - & DI, Pica & $?$ & + & + & Kochi \\
\hline 2 & 26 & $\mathrm{~F}$ & - & + & $?$ & $?$ & + & OCS, AOP, CDC & Sei & + & + & Tokyo \\
\hline 3 & 25 & $\mathrm{~F}$ & - & + & + & + & - & Ins & IMTL & + & - & Fukushima \\
\hline 4 & 18 & $\mathrm{~F}$ & - & + & + & + & + & Del, OCS, DI, CDC & Sei & + & + & Hokkaido \\
\hline 5 & 18 & $\mathrm{~F}$ & - & + & + & + & + & El, Hal, FLD, CDc & Sei & + & + & Hokkaido \\
\hline 6 & 35 & $\mathrm{M}$ & - & + & + & + & - & DI, EFD & Cho & + & + & Tokyo \\
\hline 7 & 34 & $\mathrm{M}$ & - & + & + & + & - & $?$ & GD & + & + & Hyogo \\
\hline 8 & 39 & $\mathrm{M}$ & - & + & + & + & - & $\mathrm{CDC}$ & OIM & + & + & Nagano \\
\hline 9 & 33 & $\mathrm{~F}$ & - & + & $?$ & + & + & LOM, Vio, CDC & Sei & - & + & Nagano \\
\hline 10 & 42 & $\mathrm{~F}$ & - & + & $?$ & - & + & Dem & Sei & + & + & Akita \\
\hline 11 & 36 & $\mathrm{~F}$ & + & $?$ & + & - & - & OCS, CDC & OCS & + & + & Saitama \\
\hline 12 & 25 & $\mathrm{~F}$ & - & + & + & + & - & Cop & OIM & + & + & Kagawa \\
\hline 13 & 25 & $\mathrm{~F}$ & - & + & + & + & + & Mon, CDC & Sei & + & + & Ibaraki \\
\hline 14 & $20 s$ & $\mathrm{~F}$ & - & + & + & + & - & $\mathrm{CDC}$ & Cho & + & + & Shizuoka \\
\hline 15 & 37 & $\mathrm{M}$ & - & + & + & + & $?$ & Mon & OIM & + & + & Tokyo \\
\hline 16 & 23 & $\mathrm{M}$ & - & + & + & + & + & Irr, CDC & OIM & + & + & Nara \\
\hline 17 & 26 & $\mathrm{~F}$ & - & + & + & + & + & CDC & Sei & + & + & Nara \\
\hline
\end{tabular}

Abbreviations: ? = unknown; $A c=$ acanthocyte; $A O=$ age at onset of first signs or symptoms ( $y$ ), $S=$ sex; $A O P=$ alteration of personality; $A S=$ atrophy of the corpus striatum on MRI or $\mathrm{CT} ; \mathrm{C}=$ chorein; $\mathrm{CDC}=$ cognitive decline; $\mathrm{Ch}=$ chorea; $\mathrm{CK}=$ elevated creatine kinase; $\mathrm{Cop}=\mathrm{coprolalia}$; Del = delusion; Dem = dementia; $\mathrm{DI}=$ disinhibition; $\mathrm{EFD}=$ executive function disorder; El = emotional instability; Ep = epileptic episode; $F$ = female; FLD = frontal lobe dysfunction; FS = first signs or symptoms; GD = gait disturbance; Hal = hallucination; IMTL = involuntary movement of the tongue and limbs; Ins = insomnia; Irr = irritability; LOM = lack of motivation; $\mathrm{M}=$ male; Mon = monologue; ND = not determined; NPS = neuropsychiatric symptom; OCS = obsessive-compulsive syndrome; OIM = orofacial involuntary movement; Pt = patient; Res or Ori = place of residence or origin (Japanese prefecture); Sei = seizure; Vio = violence. 
Table 2 VPS13A mutations identified in this study

\begin{tabular}{|c|c|c|c|c|c|}
\hline $\begin{array}{l}\text { Mutation } \\
\text { no. }\end{array}$ & Position & DNA change ${ }^{b}$ & $\begin{array}{l}\text { Protein } \\
\text { change }^{b}\end{array}$ & $\begin{array}{l}\text { Type of } \\
\text { mutation }\end{array}$ & Patient ID (genotype) \\
\hline $1^{a}$ & Exon 3 & c. $145-2 \mathrm{~A}>\mathrm{T}$ & Unknown & Splice & Pt 2 (ht) \\
\hline $2^{a}$ & Exon 11 & c.799C $>\mathrm{T}$ & p.R267X & Nonsense & Pt $10(\mathrm{hm})$ \\
\hline $3^{a}$ & Exon 25 & c.2532dupT & p.D845X & Nonsense & Pt 12 (ht) \\
\hline $4^{a}$ & Exon 25 & c. $2593 C>T$ & p.R825X & Nonsense & Pt 6 (ht) \\
\hline $5^{a}$ & Exon 26 & c. $2824+1 \mathrm{G}>\mathrm{T}$ & Unknown & Splice & Pt 4 (ht), Pt 5 (ht) \\
\hline $6^{a}$ & Exon 33 & c. $3562 C>T$ & p.Q1182X & Nonsense & Pt 16 (ht), Pt 17 (ht) \\
\hline $7^{a}$ & $\begin{array}{l}\text { Exon 36- } \\
45\end{array}$ & c.4115-459_5991+6444dup c & Unknown & $\begin{array}{l}\text { Large } \\
\text { duplication }\end{array}$ & Pt 16 (ht), Pt 17 (ht) \\
\hline 8 & Exon 37 & c. $4411 \mathrm{C}>\mathrm{T}$ & p.R1471X & Nonsense & $\begin{array}{l}\text { Pt } 3(\mathrm{hm}) \text {, Pt } 6(\mathrm{hm}) \text {, Pt } 7(\mathrm{hm}) \text {, Pt } 8(\mathrm{hm}) \text {, Pt } 9 \text { (hm), Pt } 13 \\
(\mathrm{hm})\end{array}$ \\
\hline $9^{a}$ & Exon 45 & c. $5881 \mathrm{C}>\mathrm{T}$ & p.R1961X & Nonsense & Pt $14(\mathrm{hm})$ \\
\hline $10^{a}$ & Exon 60 & c. $8325 \mathrm{G}>\mathrm{A}$ & p.K2775K & Splice & Pt 4 (ht), Pt 5 (ht) \\
\hline 11 & $\begin{array}{l}\text { Exon 60- } \\
61\end{array}$ & $\begin{array}{l}\text { c.8211+1232_8472- } \\
\text { 245delinsTC }\end{array}$ & p.V2738AfsX5 & Large deletion & Pt 1 (hm), Pt 2 (ht), Pt 6 (ht), Pt 11 (ht), Pt 15 (hm) \\
\hline $12^{\mathrm{a}}$ & Exon 63 & c.8653dupT & p.Y2885LfsX2 & Small insertion & Pt 12 (ht) \\
\hline $13^{a}$ & Exon 63 & c. $8667+3 A>T$ & Unknown & Splice & Pt 11 (ht) \\
\hline
\end{tabular}

Abbreviations: $\mathrm{hm}=$ homozygous; $\mathrm{ht}=$ heterozygous; $\mathrm{Pt}=$ patient.

${ }^{a}$ Novel mutation.

${ }^{\mathrm{b}}$ Mutations are described according to the nomenclature recommended by the Human Genome Variation Society (hgvs.org).

' The DNA change was predicted by the sequencing of the duplication breakpoints.

(Carrigtwohill, County Cork, Ireland). We used 2 primary antibodies, a commercially available rabbit polyclonal antibody against chorein (NBP1-85641; Novus Biologicals, Littleton, CO) and a generated rabbit polyclonal antibody against a synthetic oligopeptide antigen corresponding to amino acid residues 1816-1830 (ESDPEEENYKVPEYK) encoded by exon 43 of the VPS13A gene (Asahi Techno Glass, Chiba, Japan). Images were recorded by digital analyzers (Fujifilm LAS-1000; Fujifilm, Tokyo, Japan, or Fusion-Solo.7S; Vilber Lourmat, Collégien, France).

\section{Patients}

As the results of mutation analysis and chorein analysis, 17 Japanese patients were molecularly diagnosed with $\mathrm{ChAc}$ (table 1 ). We extracted the patient's symptoms based on the clinical records.

\section{Standard protocol approvals, registrations, and patient consents}

Total DNA, RNA, and erythrocyte membrane protein from peripheral blood samples were taken from participants who had given written informed consent. Total DNA and RNA from postmortem brains were collected after written informed consent was obtained from a family member. The research protocol and consent form were approved by the Institutional Review Board of Kagoshima University.

\section{Data availability statement}

The data sets pertaining to the current study are available from the corresponding author upon reasonable request.

\section{Results}

\section{Mutations identified by Sanger sequencing analysis}

Using Sanger sequencing, we identified 10 novel mutations and 2 previously reported mutations in 15 patients (table 2). These comprised homozygous or compound heterozygous mutations. Five novel nonsense mutations $(799 \mathrm{C}>\mathrm{T}, 2532$ dupT, $2593 \mathrm{C}>\mathrm{T}, 3562 \mathrm{C}>\mathrm{T}$, and $5881 \mathrm{C}>\mathrm{T}$ ) were found in 6 patients. In addition, 4 splice site mutations were found among 4 patients. These splice site mutations $(145-2 \mathrm{~A}>\mathrm{T}, 2824+1 \mathrm{G}>\mathrm{T}, 8325 \mathrm{G}>\mathrm{A}$, and $8667+3 A>T)$ were predicted to lead to exon skipping because of the loss of a functional splice acceptor or donor site. Exon skipping events in exons 3,26 , and 60 caused by $145-2 \mathrm{~A}>\mathrm{T}$, $2824+1 \mathrm{G}>\mathrm{T}$, and $8325 \mathrm{G}>\mathrm{A}$, respectively, were predicted to cause a frameshift resulting in a premature stop codon. On the other hand, exon 63 skipping caused by $8667+3 \mathrm{~A}>\mathrm{T}$ does not result in a frameshift because exon 63 consists of $114 \mathrm{bp}$ multiples of codon length. Nonsense mutation of $4411 \mathrm{C}>\mathrm{T}$ in exon 37 and gross deletion of exons 60-61, which have been previously reported, ${ }^{1,4,8}$ were found in 6 and 5 patients, respectively. A single nucleotide insertion mutation, which would cause a frameshift and premature stop codon, was found in patient 12 .

\section{Mutations identified by CNV analysis}

$\mathrm{CNV}$ analysis was performed in samples from patients 16 and 17 , for whom only a single heterozygous mutation was found by Sanger sequencing analysis. Quantitative PCR (qPCR) 


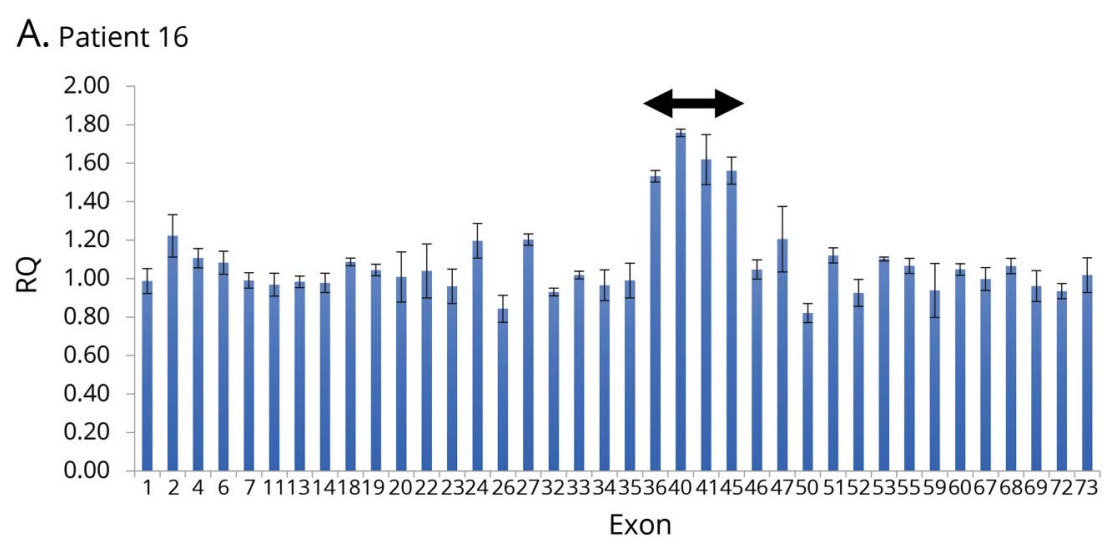

B
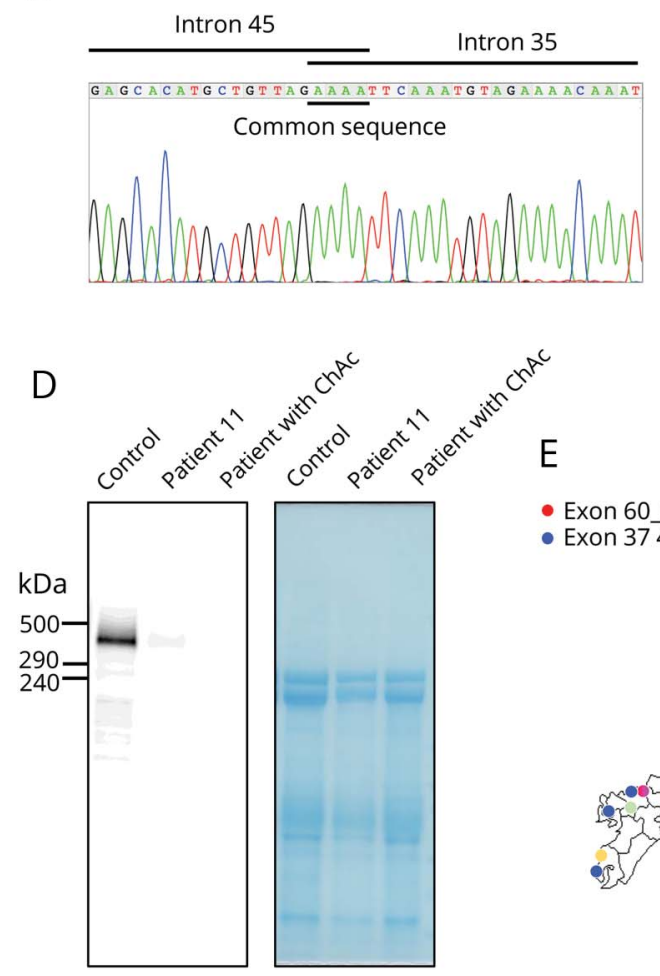

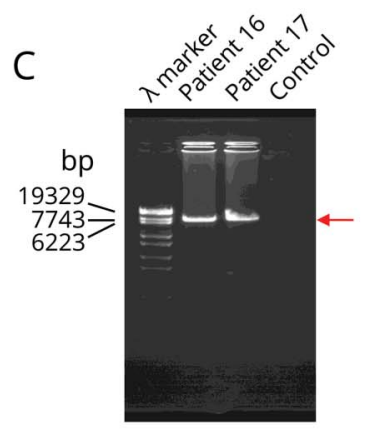

E

- Exon 60 61 del (homo)

- Exon 374411 C $>$ T R1471X (homo)

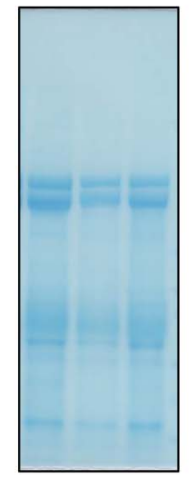

Results of qPCR for each exon of the VPS13A gene (A), results of genomic PCR performed with a forward primer located in intron 45 and reverse primer located in intron 35 (B), breakpoint in genomic sequence $(C)$, Western blotting for patient 11 (D), and geographical distribution of VPS13A mutations (E). (A) The RO value of normal controls is approximately 1.0. The extent of a predicted duplication is indicated by arrows. The figure shows the results of qPCR for each exon of the VPS13A gene in patient 16. Comparable results were observed in patient 17 . These results suggest heterozygous duplication of exon 36-45. (B) A direct connection between introns 45 and 35 was observed in the genomic DNA of patients. In this connection, a repeated AAAA sequence, which was common between the $5^{\prime}$ end of intron 35 and the $3^{\prime}$ end of intron 45, was observed. (C) Forward primer was located in intron 45 . Reverse primer was located in intron 35. Genomic PCR using this combination of primers led to an approximately 7,300 bp PCR product (theoretically 7,319 bp long; arrow) including the predicted junction in 2 patients, but no PCR product in the control. (D) Equal loading was shown by staining with Memcode Reversible Protein Stain (Thermo Fisher Scientific, Waltham, MA), shown in the right panel. Chorein immunoreactivity at $360 \mathrm{kDa}$ was observed in the normal control, but not in patients with ChAc other than patient 11. A considerable reduction in chorein levels was observed for patient 11. (E) Solid-colored circles represent patients who have homozygous mutations. Gradient-colored circles represent patients who have heterozygous mutations. Single red circles indicate exon 60-61 deletion, and single blue circles indicate exon $374411 \mathrm{C}>\mathrm{T}$ mutations. The patients carrying these 2 mutations are localized in western Japan. Some patients who could not identify their ancestral origin provided their address. The map was obtained from aoki2.si.gunma-u.ac.jp/ $\mathrm{map} / \mathrm{map} . c \mathrm{i}$. ChAc = chorea-acanthocytosis; qPCR = quantitative $\mathrm{PCR} ; \mathrm{VPS} 13 \mathrm{~A}=$ vacuolar protein sorting $13 \mathrm{~A}$. and long-range PCR suggested a single gross duplication of exons 36-45 because the relative quantification values for these exons were approximately 1.5 fold (figure, A). Consequently, we performed individually designed PCR assays for both patients to enable sequencing of the duplication breakpoints. Sanger sequencing analysis, in which the PCR template included the junction of the duplication, revealed an abnormal sequence connecting exons 45 and 36 (figure, B). Long-range PCR of gDNA covering the junction between exons 45 and 36 in both patients revealed bands corresponding to approximately 7,300 bp (figure, C). Exons 36-45 were tandemly duplicated, according to cDNA sequencing. The cDNA length of the duplication was $3754 \mathrm{bp}$, which would cause a frameshift and premature stop codon.

\section{Chorein analysis}

We performed chorein Western blotting of erythrocyte membranes of 16 patients. Western blotting revealed the complete absence of chorein in 15 patients. However, in patient 11 , chorein immunoreactivity was markedly reduced, although the chorein band remained faintly present (figure, D).

\section{Summary of 39 patients with ChAc}

A summary of the distribution of VPS13A gene mutations and clinical symptoms in a total of 39 Japanese patients with ChAc, including 22 previously reported cases, ${ }^{4}$ can be given as follows: (1) average onset age was $29.9 \pm 7.0$ years; (2) the main symptoms at onset were involuntary movements, 
epilepsy, neuropsychiatric symptoms, and/or cognitive dysfunction; (3) excluding 4 patients with the unknown data, all patients showed peripheral acanthocytosis; (4) excluding 2 patients with the unknown imaging results, 97.3\% of patients showed atrophy of bilateral caudate heads in brain MRI or CT; (5) excluding 5 patients with the unknown symptoms, $97.1 \%$ of patients showed various psychiatric symptoms or forms of cognitive dysfunction; (6) excluding 5 patients with the unknown symptoms, 94.3\% of patients showed involuntary orofacial movement; (7) excluding 2 patients with the unknown data, $91.9 \%$ of patients showed elevated creatine kinase; (8) excluding 6 patients with the unknown symptoms, $90.9 \%$ of patients showed chorea affecting all 4 limbs and trunk; (9) $55.1 \%$ of the mutations in Japanese patients with ChAc carried the 2 major mutations, exon $374411 \mathrm{C}>\mathrm{T}(\mathrm{R} 1471 \mathrm{X})$ and deletion of exons 60-61; and (10) there were individually different mutations in the remaining $44.9 \%$ of Japanese patients with ChAc.

\section{Discussion}

In the present study, we identified 11 novel pathogenic mutations and 2 previously reported mutations ${ }^{1,4,8}$ in 17 patients with $\mathrm{ChAc}$ and verified the clinical manifestations in 39 Japanese patients with ChAc. These mutations were distributed throughout the VPS13A gene, as were those in previous reports. ${ }^{4,8}$ Although we could not identify genotypephenotype correlations, over a half of the Japanese patients with ChAc carried exon $374411 \mathrm{C}>\mathrm{T}$ (R1471X) or deletion of exons $60-61$. The patients carrying these mutations were mainly localized in Tokyo and western Japan, suggesting partial founder effects (figure, E).

In the CNV analysis, we found c.4115-459_5991+6444dup. At the break point junction, a repeated AAAA sequence, which was common between the $5^{\prime}$ end of intron 35 and the $3^{\prime}$ end of intron 45, was observed. This is presumed to be a microhomology-mediated break-induced replication. ${ }^{9}$

Patient 11 carried an exon-intron junction mutation resulting in the removal of exon 63 during splicing. Although exon 63 consists of $114 \mathrm{bp}$ with multiple codon lengths, chorein Western blotting revealed a considerable reduction of chorein in patient 11 (figure, D). Because the region of chorein corresponding to exon 63 contains a tetratricopeptide repeat motif, which has been reported to be involved in proteinprotein interaction domains, we suggest that exon 63 is essential in the critically important protein interaction function of chorein.

In addition to the motor symptoms, patients with ChAc displayed high frequency of psychiatric symptoms, which may explain the previous report that VPS13A mutations predispose individuals to psychiatric disorders. ${ }^{6}$
In the present study, we summarized the distribution of VPS13A mutations and manifestations in Japanese patients with molecularly diagnosed ChAc. To understand the natural disease history and for accurate prediction of $\mathrm{ChAc}$ prognosis, much longer monitoring periods of the disease course are required.

\section{Acknowledgment}

The authors thank all patients and their families for their participation. They also thank Ms. Meguro, Ms. Nishimura, and Ms. Shimomura for their technical assistance.

\section{Study funding}

This study was funded by Grants-in Aid from the Research Committee of CNS Degenerative Diseases, Research on Policy Planning and Evaluation for Rare and Intractable Diseases, Health, Labour and Welfare Sciences Research Grants, the Ministry of Health, Labour and Welfare, Japan, and in part by the Ministry of Education, Culture, Sports, Science and Technology KAKENHI (Grant No. 17H04250 to A.S. and No. $18 \mathrm{~K} 07606$ to M.N.).

\section{Disclosure}

Disclosures available: Neurology.org/NG.

\section{Publication history}

Received by Neurology: Genetics December 19, 2018. Accepted in final form March 25, 2019.

\begin{tabular}{|c|c|c|c|}
\hline Name & Location & Role & Contribution \\
\hline $\begin{array}{l}\text { Yoshiaki } \\
\text { Nishida, } \\
\text { MD }\end{array}$ & $\begin{array}{l}\text { Kagoshima } \\
\text { University } \\
\text { Graduate School } \\
\text { of Medical and } \\
\text { Dental Sciences, } \\
\text { Kagoshima }\end{array}$ & Author & $\begin{array}{l}\text { Performed } \\
\text { laboratory work } \\
\text { and data analysis } \\
\text { and prepared the } \\
\text { manuscript }\end{array}$ \\
\hline $\begin{array}{l}\text { Masayuki } \\
\text { Nakamura, } \\
\text { MD, PhD }\end{array}$ & $\begin{array}{l}\text { Kagoshima } \\
\text { University } \\
\text { Graduate School } \\
\text { of Medical and } \\
\text { Dental Sciences, } \\
\text { Kagoshima }\end{array}$ & $\begin{array}{l}\text { Corresponding } \\
\text { author }\end{array}$ & $\begin{array}{l}\text { Supervised the } \\
\text { project, advised } \\
\text { on laboratory } \\
\text { work and data } \\
\text { analysis, and } \\
\text { prepared the } \\
\text { manuscript }\end{array}$ \\
\hline $\begin{array}{l}\text { Yuka Urata, } \\
\text { MD }\end{array}$ & $\begin{array}{l}\text { Kagoshima } \\
\text { University } \\
\text { Graduate School } \\
\text { of Medical and } \\
\text { Dental Sciences, } \\
\text { Kagoshima }\end{array}$ & Author & $\begin{array}{l}\text { Advised on } \\
\text { laboratory work }\end{array}$ \\
\hline $\begin{array}{l}\text { Kei } \\
\text { Kasamo, } \\
\text { MD }\end{array}$ & $\begin{array}{l}\text { Kagoshima } \\
\text { University } \\
\text { Graduate School } \\
\text { of Medical and } \\
\text { Dental Sciences, } \\
\text { Kagoshima }\end{array}$ & Author & $\begin{array}{l}\text { Advised on data } \\
\text { analysis }\end{array}$ \\
\hline $\begin{array}{l}\text { Hanae } \\
\text { Hiwatashi, } \\
\text { MS }\end{array}$ & $\begin{array}{l}\text { Kagoshima } \\
\text { University } \\
\text { Graduate School } \\
\text { of Medical and }\end{array}$ & Author & $\begin{array}{l}\text { Performed } \\
\text { laboratory work }\end{array}$ \\
\hline
\end{tabular}


Appendix (continued)

\begin{tabular}{|c|c|c|c|}
\hline & $\begin{array}{l}\text { Dental Sciences, } \\
\text { Kagoshima }\end{array}$ & & \\
\hline $\begin{array}{l}\text { Izumi } \\
\text { Yokoyama, } \\
\text { BS }\end{array}$ & $\begin{array}{l}\text { Kagoshima } \\
\text { University } \\
\text { Graduate School } \\
\text { of Medical and } \\
\text { Dental Sciences, } \\
\text { Kagoshima }\end{array}$ & Author & $\begin{array}{l}\text { Performed } \\
\text { laboratory work }\end{array}$ \\
\hline $\begin{array}{l}\text { Masahiro } \\
\text { Mizobuchi, } \\
\text { MD, PhD }\end{array}$ & $\begin{array}{l}\text { Nakamura } \\
\text { Memorial } \\
\text { Hospital, } \\
\text { Hokkaido }\end{array}$ & Author & $\begin{array}{l}\text { Collected clinical } \\
\text { data and blood } \\
\text { samples of study } \\
\text { patients }\end{array}$ \\
\hline $\begin{array}{l}\text { Kotaro } \\
\text { Sakurai, } \\
\text { MD, PhD }\end{array}$ & $\begin{array}{l}\text { Hokkaido } \\
\text { University } \\
\text { Graduate School } \\
\text { of Medicine, } \\
\text { Hokkaido }\end{array}$ & Author & $\begin{array}{l}\text { Collected clinical } \\
\text { data and blood } \\
\text { samples of study } \\
\text { patients }\end{array}$ \\
\hline $\begin{array}{l}\text { Yasushi } \\
\text { Osaki, MD }\end{array}$ & $\begin{array}{l}\text { Kochi Medical } \\
\text { School, Kochi }\end{array}$ & Author & $\begin{array}{l}\text { Collected clinical } \\
\text { data and blood } \\
\text { samples of study } \\
\text { patients }\end{array}$ \\
\hline $\begin{array}{l}\text { Yukari } \\
\text { Morita, MD }\end{array}$ & $\begin{array}{l}\text { Kochi Medical } \\
\text { School, Kochi }\end{array}$ & Author & $\begin{array}{l}\text { Collected clinical } \\
\text { data and blood } \\
\text { samples of study } \\
\text { patients }\end{array}$ \\
\hline $\begin{array}{l}\text { Masako } \\
\text { Watanabe, } \\
\text { MD, PhD }\end{array}$ & $\begin{array}{l}\text { Shinjyuku Neuro } \\
\text { Clinic, Tokyo }\end{array}$ & Author & $\begin{array}{l}\text { Collected clinical } \\
\text { data and blood } \\
\text { samples of study } \\
\text { patients }\end{array}$ \\
\hline $\begin{array}{l}\text { Kenji } \\
\text { Yoshida, } \\
\text { MD }\end{array}$ & $\begin{array}{l}\text { Ohta-Atami } \\
\text { Hospital, } \\
\text { Fukushima }\end{array}$ & Author & $\begin{array}{l}\text { Collected clinical } \\
\text { data and blood } \\
\text { samples of study } \\
\text { patients }\end{array}$ \\
\hline $\begin{array}{l}\text { Kiyomi } \\
\text { Yamane, } \\
\text { MD, PhD }\end{array}$ & $\begin{array}{l}\text { Ohta-Atami } \\
\text { Hospital, } \\
\text { Fukushima }\end{array}$ & Author & $\begin{array}{l}\text { Collected clinical } \\
\text { data and blood } \\
\text { samples of study } \\
\text { patients }\end{array}$ \\
\hline $\begin{array}{l}\text { Natsuki } \\
\text { Miyakoshi, } \\
\text { MD }\end{array}$ & $\begin{array}{l}\text { Tokyo } \\
\text { Metropolitan } \\
\text { Neurological } \\
\text { Hospital, Tokyo }\end{array}$ & Author & $\begin{array}{l}\text { Collected clinical } \\
\text { data and blood } \\
\text { samples of study } \\
\text { patients }\end{array}$ \\
\hline $\begin{array}{l}\text { Ryouichi } \\
\text { Okiyama, } \\
\text { MD }\end{array}$ & $\begin{array}{l}\text { Tokyo } \\
\text { Metropolitan } \\
\text { Neurological } \\
\text { Hospital, Tokyo }\end{array}$ & Author & $\begin{array}{l}\text { Collected clinical } \\
\text { data and blood } \\
\text { samples of study } \\
\text { patients }\end{array}$ \\
\hline $\begin{array}{l}\text { Takehiro } \\
\text { Ueda, MD, } \\
\text { PhD }\end{array}$ & $\begin{array}{l}\text { Kobe University } \\
\text { Graduate School } \\
\text { of Medicine, } \\
\text { Hyogo }\end{array}$ & Author & $\begin{array}{l}\text { Collected clinical } \\
\text { data and blood } \\
\text { samples of study } \\
\text { patients }\end{array}$ \\
\hline $\begin{array}{l}\text { Noritaka } \\
\text { Wakasugi, } \\
\text { MD }\end{array}$ & $\begin{array}{l}\text { National Center } \\
\text { of Neurology and } \\
\text { Psychiatry } \\
\text { Hospital, Tokyo }\end{array}$ & Author & $\begin{array}{l}\text { Collected clinical } \\
\text { data and blood } \\
\text { samples of study } \\
\text { patients }\end{array}$ \\
\hline $\begin{array}{l}\text { Yuji Saitoh, } \\
\text { MD, PhD }\end{array}$ & $\begin{array}{l}\text { National Center } \\
\text { of Neurology and } \\
\text { Psychiatry } \\
\text { Hospital, Tokyo }\end{array}$ & Author & $\begin{array}{l}\text { Collected clinical } \\
\text { data and blood } \\
\text { samples of study } \\
\text { patients }\end{array}$ \\
\hline $\begin{array}{l}\text { Takashi } \\
\text { Sakamoto, } \\
\text { MD, PhD }\end{array}$ & $\begin{array}{l}\text { National Center } \\
\text { of Neurology and } \\
\text { Psychiatry } \\
\text { Hospital, Tokyo }\end{array}$ & Author & $\begin{array}{l}\text { Collected clinical } \\
\text { data and blood } \\
\text { samples of study } \\
\text { patients }\end{array}$ \\
\hline
\end{tabular}

Appendix (continued)

\begin{tabular}{|c|c|c|c|}
\hline $\begin{array}{l}\text { Yuji } \\
\text { Takahashi, } \\
\text { MD, PhD }\end{array}$ & $\begin{array}{l}\text { National Center } \\
\text { of Neurology and } \\
\text { Psychiatry } \\
\text { Hospital, Tokyo }\end{array}$ & Author & $\begin{array}{l}\text { Collected clinical } \\
\text { data and blood } \\
\text { samples of study } \\
\text { patients }\end{array}$ \\
\hline $\begin{array}{l}\text { Ken } \\
\text { Shibano, } \\
\text { MD, PhD }\end{array}$ & $\begin{array}{l}\text { Akita Red Cross } \\
\text { Hospital, Akita }\end{array}$ & Author & $\begin{array}{l}\text { Collected clinical } \\
\text { data and blood } \\
\text { samples of study } \\
\text { patients }\end{array}$ \\
\hline $\begin{array}{l}\text { Hideki } \\
\text { Tokuoka, } \\
\text { MD }\end{array}$ & $\begin{array}{l}\text { Kobe University } \\
\text { Graduate School } \\
\text { of Medicine, } \\
\text { Hyogo }\end{array}$ & Author & $\begin{array}{l}\text { Collected clinical } \\
\text { data and blood } \\
\text { samples of study } \\
\text { patients }\end{array}$ \\
\hline $\begin{array}{l}\text { Atsushi } \\
\text { Hara, MD }\end{array}$ & $\begin{array}{l}\text { Amagasaki } \\
\text { General Medical } \\
\text { Center, Hyogo }\end{array}$ & Author & $\begin{array}{l}\text { Collected clinical } \\
\text { data and blood } \\
\text { samples of study } \\
\text { patients }\end{array}$ \\
\hline $\begin{array}{l}\text { Kazunari } \\
\text { Monma, } \\
\text { MD, PhD }\end{array}$ & $\begin{array}{l}\text { National Hospital } \\
\text { Organization } \\
\text { Higashisaitama } \\
\text { National } \\
\text { Hospital, Saitama }\end{array}$ & Author & $\begin{array}{l}\text { Collected clinical } \\
\text { data and blood } \\
\text { samples of study } \\
\text { patients }\end{array}$ \\
\hline $\begin{array}{l}\text { Katsuhisa } \\
\text { Ogata, MD, } \\
\text { PhD }\end{array}$ & $\begin{array}{l}\text { National Hospital } \\
\text { Organization } \\
\text { Higashisaitama } \\
\text { National } \\
\text { Hospital, Saitama }\end{array}$ & Author & $\begin{array}{l}\text { Collected clinical } \\
\text { data and blood } \\
\text { samples of study } \\
\text { patients }\end{array}$ \\
\hline $\begin{array}{l}\text { Keita } \\
\text { Kakuda, } \\
\text { MD }\end{array}$ & $\begin{array}{l}\text { Osaka University, } \\
\text { Osaka }\end{array}$ & Author & $\begin{array}{l}\text { Collected clinical } \\
\text { data and blood } \\
\text { samples of study } \\
\text { patients }\end{array}$ \\
\hline $\begin{array}{l}\text { Hideki } \\
\text { Mochizuki, } \\
\text { MD, PhD }\end{array}$ & $\begin{array}{l}\text { Osaka University, } \\
\text { Osaka }\end{array}$ & Author & $\begin{array}{l}\text { Collected clinical } \\
\text { data and blood } \\
\text { samples of study } \\
\text { patients }\end{array}$ \\
\hline $\begin{array}{l}\text { Takeo Arai, } \\
\text { MD, PhD }\end{array}$ & $\begin{array}{l}\text { Ikebe Clinic, } \\
\text { Shizuoka }\end{array}$ & Author & $\begin{array}{l}\text { Collected clinical } \\
\text { data and blood } \\
\text { samples of study } \\
\text { patients }\end{array}$ \\
\hline $\begin{array}{l}\text { Manabu } \\
\text { Araki, MD, } \\
\text { PhD }\end{array}$ & $\begin{array}{l}\text { National Center } \\
\text { of Neurology and } \\
\text { Psychiatry } \\
\text { Hospital, Tokyo }\end{array}$ & Author & $\begin{array}{l}\text { Collected clinical } \\
\text { data and blood } \\
\text { samples of study } \\
\text { patients }\end{array}$ \\
\hline $\begin{array}{l}\text { Takeshi } \\
\text { Fujii, MD, } \\
\text { PhD }\end{array}$ & $\begin{array}{l}\text { National Center } \\
\text { Hospital, } \\
\text { National Center } \\
\text { of Neurology and } \\
\text { Psychiatry, Tokyo }\end{array}$ & Author & $\begin{array}{l}\text { Collected clinical } \\
\text { data and blood } \\
\text { samples of study } \\
\text { patients }\end{array}$ \\
\hline $\begin{array}{l}\text { Kazuto } \\
\text { Tsukita, MD }\end{array}$ & $\begin{array}{l}\text { Kyoto University, } \\
\text { Kyoto }\end{array}$ & Author & $\begin{array}{l}\text { Collected clinical } \\
\text { data and blood } \\
\text { samples of study } \\
\text { patients }\end{array}$ \\
\hline $\begin{array}{l}\text { Haruhi } \\
\text { Sakamaki- } \\
\text { Tsukita, MD }\end{array}$ & $\begin{array}{l}\text { Kyoto University, } \\
\text { Kyoto }\end{array}$ & Author & $\begin{array}{l}\text { Collected clinical } \\
\text { data and blood } \\
\text { samples of study } \\
\text { patients }\end{array}$ \\
\hline $\begin{array}{l}\text { Akira Sano, } \\
\text { MD, PhD }\end{array}$ & $\begin{array}{l}\text { Kagoshima } \\
\text { University } \\
\text { Graduate School } \\
\text { of Medical and } \\
\text { Dental Sciences, } \\
\text { Kagoshima }\end{array}$ & Author & $\begin{array}{l}\text { Advised on data } \\
\text { analysis, } \\
\text { prepared the } \\
\text { manuscript, and } \\
\text { served as } \\
\text { a scientific } \\
\text { advisor }\end{array}$ \\
\hline
\end{tabular}




\section{References}

1. Ueno S, Maruki Y, Nakamura M, et al. The gene encoding a newly discovered protein, chorein, is mutated in chorea-acanthocytosis. Nat Genet 2001;28: 121-122.

2. Rampoldi L, Dobson-Stone C, Rubio JP, et al. A conserved sorting-associated protein is mutant in chorea-acanthocytosis. Nat Genet 2001;28:119-120.

3. Jung HH, Danek A, Walker RH. Neuroacanthocytosis syndromes. Orphanet J Rare Dis 2011;6:68.

4. Tomiyasu A, Nakamura M, Ichiba M, et al. Novel pathogenic mutations and copy number variations in the VPS13A Gene in patients with chorea-acanthocytosis. Am J Med Genet B 2011;156:620-631.
5. Ichiba M, Nakamura M, Kusumoto A, et al. Clinical and molecular genetic assessment of a chorea-acanthocytosis pedigree. J Neurol Sci 2007;263:124-132.

6. Shimo H, Nakamura M, Tomiyasu A, Ichiba M, Ueno S, Sano A. Comprehensive analysis of the genes responsible for neuroacanthocytosis in mood disorder and schizophrenia. Neurosci Res 2011;69:196-202.

7. Dobson-Stone C, Velayos-Baeza A, Filippone LA, et al. Chorein detection for the diagnosis of Chorea-acanthocytosis. Ann Neurol 2004;56:299-302.

8. Dobson-Stone C, Danek A, Rampoldi L, et al. Mutational spectrum of the CHAC gene in patients with chorea-acanthocytosis. Eur J Hum Genet 2002;10:773-781.

9. Ottaviani D, LeCain M, Sheer D. The role of microhomology in genomic structural variation. Trends Genet 2014;30:85-94. 


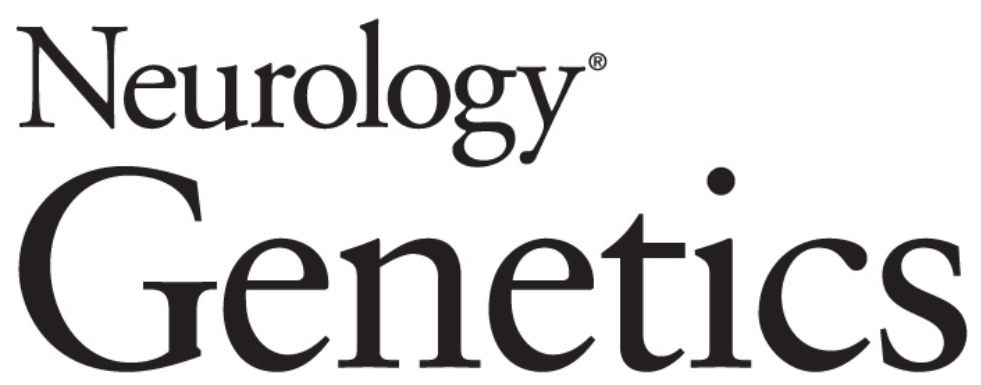

Novel pathogenic VPS13A gene mutations in Japanese patients with chorea-acanthocytosis

Yoshiaki Nishida, Masayuki Nakamura, Yuka Urata, et al. Neurol Genet 2019;5;

DOI 10.1212/NXG.0000000000000332

This information is current as of May 1, 2019

Neurol Genet is an official journal of the American Academy of Neurology. Published since April 2015, it is an open-access, online-only, continuous publication journal. Copyright Copyright $@ 2019$ The Author(s). Published by Wolters Kluwer Health, Inc. on behalf of the American Academy of Neurology.. All rights reserved. Online ISSN: 2376-7839.

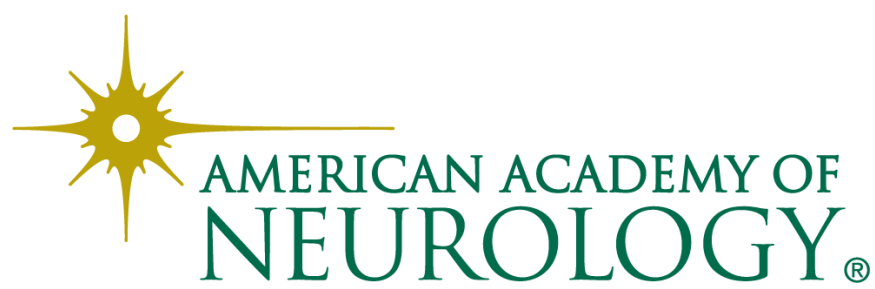




\section{Updated Information \& Services}

References

Citations

Subspecialty Collections

Permissions \& Licensing

Reprints including high resolution figures, can be found at: http://ng.neurology.org/content/5/3/e332.full.html

This article cites 9 articles, 0 of which you can access for free at: http://ng.neurology.org/content/5/3/e332.full.html\#\#ref-list-1

This article has been cited by 4 HighWire-hosted articles: http://ng.neurology.org/content/5/3/e332.full.html\#\#otherarticles

This article, along with others on similar topics, appears in the following collection(s):

All Clinical Neurology

http://ng.neurology.org//cgi/collection/all_clinical_neurology All Cognitive Disorders/Dementia http://ng.neurology.org//cgi/collection/all_cognitive_disorders_dementi a All Epilepsy/Seizures

http://ng.neurology.org//cgi/collection/all_epilepsy_seizures Chorea

http://ng.neurology.org//cgi/collection/chorea

Information about reproducing this article in parts (figures,tables) or in its entirety can be found online at:

http://ng.neurology.org/misc/about.xhtml\#permissions

Information about ordering reprints can be found online: http://ng.neurology.org/misc/addir.xhtml\#reprintsus

Neurol Genet is an official journal of the American Academy of Neurology. Published since April 2015, it is an open-access, online-only, continuous publication journal. Copyright Copyright $\odot 2019$ The Author(s). Published by Wolters Kluwer Health, Inc. on behalf of the American Academy of Neurology.. All rights reserved. Online ISSN: 2376-7839.

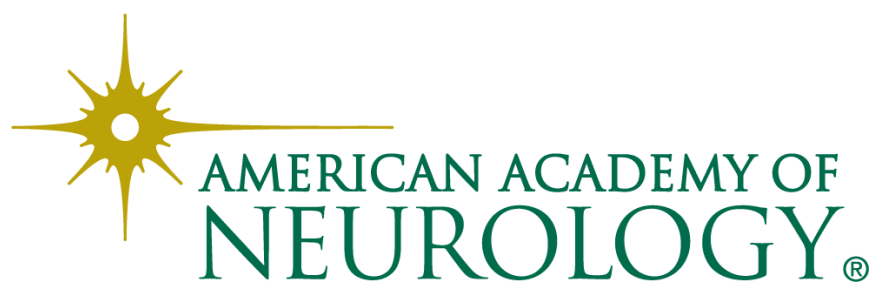

